\title{
Phytochemical Investigation and Biological Activities of Some Saharan Plants from Hoggar
}

\author{
Faiza Chaib ${ }^{1,2,3}$, Rabéa Sahki $^{4}$, Nasreddine Sabaou ${ }^{5}$, Wahiba Rached ${ }^{1} \&$ Malika Bennaceur ${ }^{1,2}$ \\ ${ }^{1}$ Laboratoire de Biochimie Végétale, Département de Biologie, Faculté des sciences de la nature et de la vie, \\ Université Oran1Ahmed Benbella, Oran, Algérie \\ ${ }^{2}$ Laboratoire de Recherche sur les Zones Arides, El Alia Bab Ezzouar, Alger, Algérie \\ ${ }^{3}$ EcoleMérieux, Ecole Supérieure des Technologies de la Santé, Oran, Algérie \\ ${ }^{4}$ InstitutNational de Recherche Forestière, Tamanrasset, Algérie \\ ${ }^{5}$ Ecole Normale Supérieure, Kouba, Alger, Algérie \\ Correspondence: Malika Bennaceur, Université Oran1Ahmed Benbella,Faculté des sciences de la nature et de la \\ vie, Département de Biologie, Laboratoire de Biochimie Végétale, BP 1524 El-Menouar. Oran 31000, Algérie. \\ Tel: 213-551-074-090. E-mail: bennaceurmalika@gmail.com \\ Faiza Chaib, Université Oran1Ahmed Benbella,Faculté des sciences de la nature et de la vie, Département de \\ Biologie, Laboratoire de Biochimie Végétale, BP 1524 El-Menouar. Oran 31000, Algérie. E-mail: \\ faizachaib@yahoo.fr
}

Received: March 10, 2015 Accepted: April 28, 2015 Online Published: June 15, 2015

doi:10.5539/jas.v7n7p163 URL: http://dx.doi.org/10.5539/jas.v7n7p163

\begin{abstract}
Traditional medicine has a great impact on aboriginal heal thin Algerian Sahara and particularly in Hoggar. It is based on the use of local plants.

This study is based on phytochemical screening. Antioxidant activity evaluation by two methods of 1,1-diphenyl-2-picrylhydrazyl (DPPH): bioautography and spectrophotometric assay, and microbiological activity of twelve plants species from nine families sampled in Hoggar.

The antioxidant activity revealed by the bioautography (DPPH) showed a positive activity on aqueous extracts of ten species among the twelve assayed. Both species Lavandula pubescens subesp. antinea and Mentha longifolia (Lamiaceae) have reported a significant activity compared to the others.

The comparison of antiradical activity bybioautography and phytochemical study by TLC showed the presence of cardiotonic glycosides, saponins and flavonoids which could be responsible of antioxidant activity or some species.

The antimicrobial activity assay showed that plant aqueous extracts were inefficient on the majority of tested strains except for Balanites aegyptica extract on Bacillus subtilis ATCC6633. Moreover, remarkable antifungal activity of Aerva javanica aqueous extracts on four fungal strains such as Candida albicans C200, Aspergillus flavus AF1, Aspergillus carbonarius M333, Fusarium culmorum FC1was observed.
\end{abstract}

Keywords: Hoggar, medicinal plants, phytochemistry, antioxidant activity, antimicrobial activity

\section{Introduction}

Plants use for therapeutic purpose was reported in the ancient Arab literatures. In Africa, the therapeutic plants action was known by our ancestors and our parents in an empirical way (Karou et al., 2003). Until now, both medicines: traditional and modern are practiced. To achieve a better knowledge of this African medicine, several phytochemical investigations have been made in order to bring a justification and a scientific validation to its traditional use (Yemoa et al., 2008). Many work undertaken in ethnopharmacology field, showed that the used plants in traditional medicine which were tested are often considered as effective plants in the pharmacological models on the other hand, they would be almost deprived of toxicity.

Several works in the world were conducted, they are based on biological activities, for instance Bo Huang et al. (2011) in China and Kaisoona et al. (2011) in Thailand have tested the antioxidant activity of herbal medicine. 
The antimicrobial activity was treated by De Oliveira et al. (2011) for Brazilian plants and Al-Bayati (2009) for Iraqi ones.

Algeria possesses a rich plant genotypes used in traditional pharmacopoeia to treat several diseases, like diabetes, cardiovascular diseases and other pathologies (Bellakhdar et al.,1991; Ziyyat et al., 1997; Eddouks et al., 2002).

Several works were carried out in Algeria on plants of medicinal interest. These plants were evaluated for their richness in polyphenols and their antioxidant, antimicrobial, and antidiabetic proprieties (Djeridane et al., 2006).

Zaabat et al. (2010) conducted a phytochemical study on Marrubium desertii. He isolated an original diterpene of labdane type, a flavonoïd and a glycosyled phenyl propanoïdes. These compounds were subjected to biological study as antioxidant, antibacterial and antigenotoxic activities.

The work carried out on fifty-six species of medicinal plants harvested in different areas of Algeria showed the richness of secondary metabolites and biological activity like the antioxidant and the acetyl cholinesterase activity (Benamar et al., 2010; Rached et al., 2010).

Despite many studies carried on biological activity of prospected plants in Algeria, many species remain still not investigated. Indeed, central Sahara hosts vegetal species resistant to extreme aridity conditions.

This natural richness indicated various foods, cosmetic and medicinal virtues (Sahki et al., 2004). Until now, traditional healers belonging toTuareg tribes use these plants for treating several diseases. In this context, our investigation was conducted to evaluate the antioxidant and antimicrobial activities of twelve Hoggar plants species.

\section{Materials and Methods}

\subsection{Biotope of Studied Plants}

The Ahaggar (Hoggar) is an integral part of the central Sahara subdivision; it is constituted by mountain range rising to over $3000 \mathrm{~m}$ of altitude. It is located at the extreme south of Algeria and was approximately between $21^{\circ}-25^{\circ}$ North latitude and between $3^{\circ}-6^{\circ}$ West longitude (Gast, 1968). It covers a surface of approximately $554,000 \mathrm{Km}^{2}$, which represents the quarter of Algeria total surface (Sahki, 2012). The Ahagar flora is characterized by vegetal formations, especially tropical and saharo-sindian, which is concentrated mainly in Oued's bank and dry valley at middle and low altitudes. On the contrary, higher altitudes are less arid, then host many microclimates allowing mainly Mediterranean, endemic and endemic relic flora development.

Since ancient era, Tuaregs (inhabitants of Ahaggar) were interested by plants curative virtues growing in their natural environment. Generally, this traditional culture was transmitted by nomadic and semi-sedentary population, despite of sciences progress.

Ethnomedicinal surveys conducted with traditional healers's Ahaggar reported that different plant parts (leaves, roots, fruits, bark, seeds, flowers, wood) are used directly in the fresh or powder form, mixed with other plants, tea, honey or animal fats. Many obtained preparations were generally administered in the form of teas, baths, syrup or extract added to food or drink (Sahki, 1998).

\subsection{Plant Material}

The studied sample is represented by aerial parts of fifteen plants harvested from Hoggar area in May, 2009 and February, 2010 (Table 1). These plants were identified by Dr. Sahki, member of INRF (National Institute of Forest Research) and then were put in herbarium (Sahki et al., 2004). The samples were dried at free air in the darkness or in a drying oven at $50{ }^{\circ} \mathrm{C}$ during $24 \mathrm{~h}$ and then crushed to form a fine powder. 
Table 1. List of studied plants and their traditional medicinal uses (Sahki, 1998; Sahki et al., 2004)

\begin{tabular}{|c|c|c|}
\hline Vegetal species & Used organs & Therapeutic indications \\
\hline Solenostemma argel & Leaves, fruits and flowers & Respiratory affections, rheumatisms, angina. Such stem is for helping wound healing \\
\hline Aervajav anica & $\begin{array}{l}\text { Roots, leaves, flowers and } \\
\text { stems leaves }\end{array}$ & Viper bites and scorpion stings. Soap making \\
\hline Deverra scoparia & Leaves stems and flowers & $\begin{array}{l}\text { Used as condiments, infusion relieves Renal colic, rheumatism, colds, irritable bowel } \\
\text { syndrome }\end{array}$ \\
\hline Pentzia monodiana & - & Plant grazed, not used in traditional medicine \\
\hline Pulicaria incisa & leaves & Decoction used against the colds, the flu and the tachycardia \\
\hline Maerua crassifolia & Leaves and fruits & $\begin{array}{l}\text { Antipyretic, dental caries, vomiting and against scorpion stings. The Fruit pleasant taste } \\
\text { consumed scandy }\end{array}$ \\
\hline Anabasis articulata & & $\begin{array}{l}\text { Forage plant. The stems are used to treat the skin diseases of camels. Crushed they give } \\
\text { the soap }\end{array}$ \\
\hline $\begin{array}{l}\text { Lavandula } \\
\text { pubescenssubsp. } \\
\text { antinea }\end{array}$ & Leaves stems and flower & $\begin{array}{l}\text { Infusion used against the rheumatism and the spasms. These is antiseptic of the } \\
\text { respiratory and urinary tracts. These is used as a condiment and flavoring. }\end{array}$ \\
\hline Marrubium desertii & Leaves buds & $\begin{array}{l}\text { Decoction used against bloating and diarrhea, they have efficient avirtues against } \\
\text { tachycardia }\end{array}$ \\
\hline Mentha longifolia & Leaves, flowers and fruits & $\begin{array}{l}\text { The infusions of fresh leaves are digestives, stomachic and calming. The flowers and } \\
\text { fruits are astringent infusion. The leaves are used as condiment infusions }\end{array}$ \\
\hline $\begin{array}{l}\text { Cymbopogon } \\
\text { schoenanthus }\end{array}$ & $\begin{array}{l}\text { Stems, leaves flowers and } \\
\text { Roots }\end{array}$ & $\begin{array}{l}\text { Used in decoction, they relieve kidney's pain, intestinal disorders and food poisoning; } \\
\text { they used in rheumatic and sinusitis. It treats the wounds of dromedary by cataplasm }\end{array}$ \\
\hline Balanites aegyptiaca & $\begin{array}{l}\text { Fruits, barks, roots, leaves, } \\
\text { oils extracts by almond }\end{array}$ & $\begin{array}{l}\text { Decoction of the bark is used to relieve throat. Fruit relieve sinusitis, tonsillitis and } \\
\text { protect the face against the cold. The leaves are laxative, digestive, anthelmintic, relieve } \\
\text { rheumatic pain, nausea, boils and dental caries. The oily paste extracted from the almond } \\
\text { of the fruits used in cosmetics and for treating scabies dromedaries }\end{array}$ \\
\hline
\end{tabular}

\subsection{Extraction}

The samples were extracted by heat under reflux, $10 \mathrm{~g}$ of plant powder were put in $100 \mathrm{ml}$ of distilled water. This operation is repeated three times during half an hour. The three obtained filtrated were mixed, lyophilized and stored at $-4{ }^{\circ} \mathrm{C}$ until further use.

\subsection{Solution Preparation}

The freeze-dried powder was weighed and dissolved in methanol at the concentration of $5 \mathrm{mg} / \mathrm{ml}$ for all the samples.

\subsubsection{Phytochemical Screening by TLC}

The phytochemical analyses of the plant extracts were carried out following the methods of (Wagner \& Bladt, 1996), the chromatographic analyses were achieved out on plates of CCM silica gel $F_{254}$ (Merck). Several systems were used, the chromatograms are observed under U.V at 254 and $365 \mathrm{~nm}$. After revelation, the detected phytoconstituants are: flavonoids, saponins, terpenoïds, glycosides cardiotonics, sesquiterpenes lactones, quinones and lignans.

\subsubsection{Total Phenolic Content Determination}

The total phenolic content is estimated using Folin-Ciocalteu's method (Singleton \& Rossi, 1965). $100 \mu$ of sample was dissolved in $500 \mu \mathrm{l}$ of Folin-Ciocalteu reagent (1/10 dilution). The solution were mixed and incubated at room temperature during $5 \mathrm{mn}$. Then, $1500 \mu \mathrm{l}$ of saturated sodium carbonate $(2 \%)$ was added. The final mixture was mixed and then incubated for one hour in the dark at room temperature. The absorbance was read at $765 \mathrm{~nm}$. 


\subsubsection{Total Flavonoid Content Determination}

Total flavonoid contents were determined by the method of (Kim et al., 2003). $500 \mu \mathrm{l}$ of the methanolic samples were added to $1500 \mu \mathrm{l}$ of distilled water and $150 \mu$ lof sodium nitrite $\left(\mathrm{NaNO}_{2}\right)$ at $5 \%(\mathrm{~m} / \mathrm{v})$. After $5 \mathrm{~min}, 150 \mu \mathrm{l}$ of aluminum chloride $\left(\mathrm{AlCl}_{3}\right)$ at $10 \%(\mathrm{~m} / \mathrm{v})$ was added. 11 minutes later was added $500 \mu \mathrm{l}$ of $1 \mathrm{M} \mathrm{NaOH}$. The solution was vortexed then the absorbance was measured at $510 \mathrm{~nm}$.

\subsubsection{Total Tannin Content Determination}

$100 \mu \mathrm{l}$ of methanolic sample extract in pure methanol was added to $600 \mu \mathrm{l}$ vanillin at $4 \%$ in absolute methanol and $300 \mu \mathrm{L}$ of concentrated HCI (Burns et al., 1971). Incubation is conducted in water bath at $30^{\circ} \mathrm{C}$ during 20 min. All the samples were maintained in the dark. The absorbance is read at $500 \mathrm{~nm}$, we used as a control, a solution containing methanol instead of the vanillin solution.

\subsection{Biological Activities}

\subsubsection{Antiradical Activity Determination by Thin Layer Chromatography (TLC) (Bioautography)}

The 2,2-diphenyl-1-picryl hydrazyle (DPPH) method was used to determine antiradical activity according to (Dominguez et al., 2005). The antioxidant test is carried on thin layer chromatography, $100 \mu \mathrm{g}$ of plant extract are deposited on aluminum plates of silica $\mathrm{F}_{254}$. The chromatograms are developed in a mixture of several solvents. After separation and drying, the plates are pulverized with a $0.2 \%$ solution of DPPH in methanol.

\subsubsection{Test DPPH by Spectrophotometry Dosage}

The method of (Blois, 1958) modified by (Rached, 2010) includes only extracts which presented antiradical activity revealed by bioautography. The test is carried out according to the following stages: the methanolic solution of DPPH $(1950 \mu \mathrm{l})$ at a concentration of $6.10^{-5} \mathrm{M}$ was mixed with $50 \mu \mathrm{l}$ of different extract concentration (5-10-12.5-15-20 $\mu \mathrm{g} / \mathrm{ml})$. Then, the mixture was incubated at room temperature in darkness for $1 \mathrm{~h}$. The absorbance of each extract containing DPPH was read at $517 \mathrm{~nm}$ using a UV-visible spectrophotometer (8500P Double-Beam spectrophotometer). The percentage of inhibition (PI) of the extract is calculated according to the equation:

Where,

$$
\mathrm{PI}=\frac{\text { A neg.control }- \text { A sample }}{\text { A neg.control }} \times 100
$$

A neg. control is the absorption of the negative control solution (containing only DPPH);

A sample is the absorption in the presence of the plant extract in DPPH solution;

Quercetin and the BHA (Butyl Hydroxy Anisole) are used as the positive controls.

The experiment is repeated three times for each sample and the value is expressed by an average \pm standard of deviation.

\subsubsection{The Antimicrobial Activity Evaluation}

The antibacterial and antifungic activities of extracts were investigated.

1) The Bacterial and Antifungal Strains Tested

The strains of Bacillus subtilis ATCC6633, Staphylococcus aureus, Escherichia coli E195, Klebsiella pneumoniae E40, Candida albicans C200, Aspergillus flavus AF1, Aspergillus carbonarius M333, Fusarium culmorum FC1 were sampled from Bejaia and Algiers hospitals, they were provided by the laboratory of microbiology of the (ENS).

2) Determination of Antimicrobial Activity

Antibacterial activity of the aqueous extract of the sample was evaluated by paper discs diffusion method. The stock concentration was prepared from the aqueous extracts of the tested plants at a concentration of $200 \mathrm{mg} / \mathrm{ml}$. After that, sterile filter papers ( $9 \mathrm{~mm}$ diameter) were impregnated with $5 \mathrm{mg}$ and $10 \mathrm{mg}$ of extract by disc. All disks prepared were then dried in air and sterilized under UV.

The impregnated discs by various extracts are then deposited delicately on the surface of the agar medium. The antibacterial activity was determined by measurement of inhibition zone around each paper disc. Incubation was done at $30{ }^{\circ} \mathrm{C}$ during $18 \mathrm{~h}$ to $24 \mathrm{~h}$ for bacteria strains and $36 \mathrm{~h}$ to $48 \mathrm{~h}$ for fungi and yeast strains.

\subsection{Statistical Analysis}

The results are expressed on average \pm standard deviation. ANOVA (variance analysis) compare several groups 
by using the Duncan test. For comparison between two groups, the student test was used. The values were significant at $\mathrm{P}<0.05$.

\section{Results}

\subsection{Phytochimical Result by TLC}

Phytochimical study results of the tested vegetal extract were indicated in Table 2. The orange, yellow, blue, green spots observed on the chromatogram under UV/365 nm correspond to several secondary metabolites classes. The chromatograms showed a wealth of metabolites for some extracts. A comparison is made in parallel between the phytochimical and TL Cbioautography study by DPPH in order to focus on the active phytoconstituants.

\subsection{Total Polyphenols, Flavonoids and Tannins Determination}

The polyphenol content of the studied extracts has $230.003 \pm 8.423 \mathrm{mg}$ range for Lavandula antinea leaves and $33.635 \pm 0.477 \mathrm{mg}$ of gallic acid equivalent per gram of freeze-dried matter in Balanites aegyptiaca (aerial parts).The flavonoïds content vary between $94.483 \pm 4.137$ and $9.537 \pm 0.657 \mathrm{mg}$ of catechin equivalent per gram of freeze-dried matter of Lavandula antinea (stems) and Balanites aegyptiaca (aerial parts). Tannins are present in $21.36 \pm 0.33$ mgrange for Solenostemma argel leaves and $3.3 \pm 0.92 \mathrm{mg}$ of catechin equivalent per gram of matter freeze-dried in Mentha longifolia stems.

Lavandula antinea (stems) given an $\mathrm{IC}_{50}$ value of $10.352 \pm 0.388$. This value was determined in comparison to the reference value of $\mathrm{IC}_{50}$ BHA which is estimated to $4.457 \pm 0.07$.

\subsection{Biological Activities}

\subsubsection{Antioxidant Activity by Bioautography}

The free radicals activity of fifteen aqueous extracts were investigated. The obtained results showed that thirteen extracts reacted with the DPPH, illustrated by the appearance of yellow bands on a purple background. Some of these extracts had appeared instantaneously but others appeared after 30 minutes.

\subsubsection{DPPH Dosage Assay}

The absorbance measurement (optical density) was conducted by a spectrophotometer at $514 \mathrm{~nm}$. From the obtained values, the percentage of inhibition was calculated by using the formula the formula given in one methodology part.

Table 2 represents $\mathrm{IC}_{50}$ values (corresponding to $50 \%$ of inhibition) of the extracts and represents the antioxidant activities. The aqueous extract of Lavandula antinea (stems) given an $\mathrm{IC}_{50}$ value of $10.352 \pm 0.388$. This value was determined in comparison to the reference value of $\mathrm{IC}_{50}$ BHA which is estimated to $4.457 \pm 0.07$. 
Table 2. Chemical composition of studied plants

\begin{tabular}{|c|c|c|c|c|c|c|c|c|c|c|c|}
\hline \multirow[b]{2}{*}{ Family, species } & \multirow[b]{2}{*}{ 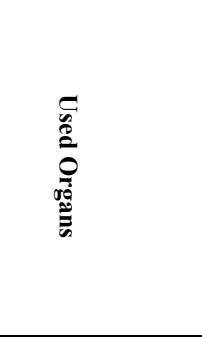 } & \multirow{2}{*}{\multicolumn{2}{|c|}{$\begin{array}{l}\text { DPPH } \\
\text { Bioautography } \\
\mathrm{IC}_{50}{ }^{*}\end{array}$}} & \multirow[b]{2}{*}{$\begin{array}{l}\text { Polyphenols } \\
\text { contents* }\end{array}$} & \multirow[b]{2}{*}{$\begin{array}{l}\text { Flavonoids } \\
\text { contents*** }\end{array}$} & \multirow[b]{2}{*}{$\begin{array}{l}\text { Tannins } \\
\text { contents*** }\end{array}$} & \multicolumn{5}{|c|}{ Chemical groups } \\
\hline & & & & & & & 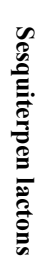 & 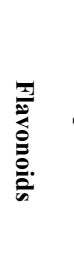 & 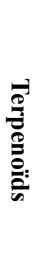 & Oే & 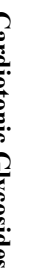 \\
\hline \multicolumn{12}{|l|}{ Asclepiadaceae } \\
\hline Solenostemma argel & Leaves & + & $100.627 \pm 6.454$ & $97.710 \pm 1.109$ & $17.834 \pm 2.235$ & $21.36 \pm 0.33$ & - & +++ & - & +++ & - \\
\hline \multicolumn{12}{|l|}{ Amaranthaceae } \\
\hline Aerva javanica & Aerial parts & + & $57.59 \pm 0.799$ & $80.899 \pm 1.995$ & $23.263 \pm 3.529$ & $11.7 \pm 0.26$ & - & + & - & +++ & - \\
\hline \multicolumn{12}{|l|}{ Apiaceae } \\
\hline Deverra scoparia & Aerial parts & + & $97.399 \pm 2.535$ & $68.946 \pm 6.397$ & $9.640 \pm 1.477$ & $8.42 \pm 0.49$ & - & +++ & - & ++ & - \\
\hline \multicolumn{12}{|l|}{ Asteraceae } \\
\hline Pentzia monodiana & Aerial parts & + & $56.873 \pm 0.583$ & $72.311 \pm 1.312$ & $30.797 \pm 1.010$ & $11.58 \pm 0.54$ & - & +++ & - & ++ & - \\
\hline Pulicaria incisa & Stems and leaves & + & $51.163 \pm 0.358$ & $63.164 \pm 2.910$ & $27.537 \pm 2.024$ & $7.1 \pm 0.43$ & - & - & - & +++ & - \\
\hline \multicolumn{12}{|l|}{ Capparaceae } \\
\hline Maerua crassifolia & leaves & + & $122.893 \pm 2.852$ & $35.129 \pm 2.291$ & $15.720 \pm 1.046$ & $10.2 \pm 0.34$ & - & + & - & - & - \\
\hline \multicolumn{12}{|l|}{ Chenopodiaceae } \\
\hline Anabasis articulata & Aerial parts & - & ND & ND & ND & ND & - & - & - & - & - \\
\hline \multicolumn{12}{|l|}{ Lamiaceae } \\
\hline Lavandula antinea & Leaves steams & + & $13.834 \pm 0.336$ & $230.003 \pm 8.423$ & $90.740 \pm 1.184$ & $10.36 \pm 0.32$ & + & +++ & + & + & + \\
\hline Lavandula antinea & Leaves & + & $10.352 \pm 0.388$ & $126.997 \pm 2.735$ & $94.483 \pm 4.137$ & $9.06 \pm 0.48$ & - & - & + & +++ & + \\
\hline Marrubium desertii & Steams & + & $73.149 \pm 2.662$ & $44.033 \pm 1.599$ & $28.040 \pm 3.071$ & $11.58 \pm 0.79$ & - & - & - & + & - \\
\hline Marrubium desertii & Leaves & - & ND & ND & ND & ND & - & - & - & - & - \\
\hline Mentha longifolia & Steams & + & $17.262 \pm 0.552$ & $131.066 \pm 4.314$ & $94.406 \pm 7.537$ & $6.12 \pm 0.44$ & - & +++ & - & - & + \\
\hline Mentha longifolia & Leaves & + & $19.6 \pm 0.822$ & $103.310 \pm 4.036$ & $93.469 \pm 10.734$ & $3.3 \pm 0.92$ & - & +++ & - & - & + \\
\hline \multicolumn{12}{|l|}{ Poaceae } \\
\hline Cymbopogon schoenanthus & Aerial parts & + & $102,717 \pm 2,056$ & $64.962 \pm 1.142$ & $19.354 \pm 1.841$ & $11.86 \pm 0.55$ & - & + & - & - & - \\
\hline \multicolumn{12}{|l|}{ Zygophyllaceae } \\
\hline Balanites aegyptiaca & Aerial parts & + & $147.419 \pm 2.73$ & $33.635 \pm 0.477$ & $9.537 \pm 0.657$ & $5.82 \pm 0.27$ & + & ++ & - & + & + \\
\hline BHA & & & $4.457 \pm 0.07$ & & & & & & & & \\
\hline Quercetin & & & $1.119 \pm 0.0696$ & & & & & & & & \\
\hline
\end{tabular}

Note. ${ }^{*}$ Antioxidant activity expressed as $\mu \mathrm{g} \mathrm{ml}^{-1} .{ }^{* *}$ Total phenolics contents expressed as $\mathrm{mg}$ gallic acid in $\mathrm{g}$ of freeze-dried extract. $* * *$ flavonoids and tannins contents as $\mathrm{mg}$ catechin $\mathrm{g}^{-1}$ of freeze-dried extract. nd: Not determined, +: Positive result, -: Negative results. Data expressed as Mean \pm SD from triplicate experiments. BHA: Butyl-hydroxyanisole.

\subsubsection{Antimicrobial Activity Determination}

The antibacterial and antifungal activities of the various extracts were estimated by inhibition zone diameter evaluation after $12 \mathrm{~h}$ and $24 \mathrm{~h}$ incubation at $30^{\circ} \mathrm{C}$ temperature for two concentrations $5 \mathrm{mg} / \mathrm{ml}$ and $10 \mathrm{mg} / \mathrm{ml}$.

1) Inhibition Zone Diameter for $5 \mathrm{mg} / \mathrm{ml}$ Concentration

After 24 hours of incubation, inhibition zones of $12 \mathrm{~mm}$ are observed on only 04 extracts concerning gram positive 
bacterial Bacillus subtilis. After 48 hour, significant inhibition is noticed for Aspergillus flavus (Tables 3 \& 4).

Table 3. Inhibition zone diameter of active plants extracts against Bacillus subtilis strain at $5 \mathrm{mg}$ concentration

\begin{tabular}{lllllll}
\hline Strains & $\begin{array}{l}\text { Balanites } \\
\text { aegyptiaca } \\
\text { (Oued Tounine) }\end{array}$ & $\begin{array}{l}\text { Balanites } \\
\text { aegyptiaca } \\
\text { (Tin Tahounek) }\end{array}$ & $\begin{array}{l}\text { Lavandula } \\
\text { antinea } \\
\text { (leaves) }\end{array}$ & $\begin{array}{l}\text { Lavandula } \\
\text { antinea } \\
\text { (stems) }\end{array}$ & $\begin{array}{l}\text { Pentzia } \\
\text { monodiana }\end{array}$ & $\begin{array}{l}\text { Pulicaria incise } \\
\text { (Oued Taharart 1130M) }\end{array}$ \\
\hline $\begin{array}{l}\text { Bacillus subtilis } \\
\text { ATCC } 6633\end{array}$ & $11 \mathrm{~mm}$ & $10 \mathrm{~mm}$ & $12 \mathrm{~mm}$ & $12 \mathrm{~mm}$ & $12 \mathrm{~mm}$ & $12 \mathrm{~mm}$ \\
\hline
\end{tabular}

Table 4. Inhibition zone diameter of active plants extracts against Aspergillus flavus at $5 \mathrm{mg}$ concentration

\begin{tabular}{llllll}
\hline Strains & $\begin{array}{l}\text { Cymbopogon } \\
\text { schoenanthus } \\
\text { (aerial parts) }\end{array}$ & $\begin{array}{l}\text { Mentha longifolia } \\
\text { (stems) }\end{array}$ & Aerva javanica & $\begin{array}{l}\text { Solenostema argel } \\
\text { (leaves) }\end{array}$ & $\begin{array}{l}\text { Pulicaria incise } \\
\text { (leaves and stems) }\end{array}$ \\
\hline Aspergillus flavus & $11 \mathrm{~mm}$ & $13 \mathrm{~mm}$ & $13 \mathrm{~mm}$ & $11 \mathrm{~mm}$ & $11 \mathrm{~mm}$ \\
\hline
\end{tabular}

2) Inhibition Zone Diameter for $10 \mathrm{mg} / \mathrm{ml}$ Concentration

Concerning E. coli E195 and Staphylococcus aureus, strains, the results were negative for all the tested extracts.

The results of inhibition zone diameter for Bacillus subtilis, showed that this strains sensitive to Pentzia monodiana, Lavandula antinea and Pulicaria incise extracts. Nevertheless, these extracts did not develop any inhibition zone for gram negative bacteria, yeasts and fungi.

Mentha longifolia and Aerva javanica extracts at $25 \mu \mathrm{l}(5 \mathrm{mg} / \mathrm{ml})$ concentration showed a significant inhibition of Aspergillus flavusfungus with $13 \mathrm{~mm}$ diameter. For $50 \mu \mathrm{l}$ concentration, results were not significant for all organisms and sample. The Balanites aegyptiaca extract shown the most important inhibition zone for Bacillus subtilis (Table 5).

Table 5. Inhibition zone diameter of active plants extracts at $10 \mathrm{mg}$ concentration

\begin{tabular}{|c|c|c|c|c|c|c|}
\hline Extracts & $\begin{array}{l}\text { Bacillus } \\
\text { subtilis } \\
\text { ATCC6633 }\end{array}$ & $\begin{array}{l}\text { Klebsiella } \\
\text { pneumoniae } \\
\text { E40 }\end{array}$ & $\begin{array}{l}\text { Candida } \\
\text { albicans } \\
\mathrm{C} 200\end{array}$ & $\begin{array}{l}\text { Aspergillus } \\
\text { flavus } \mathrm{AF} 1\end{array}$ & $\begin{array}{l}\text { Aspergillus } \\
\text { carbonarius } \\
\text { M333 }\end{array}$ & $\begin{array}{l}\text { Fusarium } \\
\text { culmorum } \\
\text { FC1 }\end{array}$ \\
\hline Balanites aegyptiaca (Oued Tounine) & $13 \mathrm{~mm}$ & $10 \mathrm{~mm}$ & 0 & 0 & 0 & 0 \\
\hline Balanites aegyptiaca (Tin Tahounek) & $13 \mathrm{~mm}$ & $10 \mathrm{~mm}$ & 0 & 0 & 0 & 0 \\
\hline Cymbopogon schoenanthus & $10 \mathrm{~mm}$ & $10 \mathrm{~mm}$ & 0 & 0 & 0 & 0 \\
\hline Lavandula antinea leaves & $12 \mathrm{~mm}$ & $10 \mathrm{~mm}$ & 0 & 0 & 0 & 0 \\
\hline Lavandula antiea stems & $11 \mathrm{~mm}$ & $10 \mathrm{~mm}$ & 0 & 0 & 0 & 0 \\
\hline Maerua crassifolia & 0 & 0 & 0 & 0 & 0 & 0 \\
\hline Marribium desertii leaves & 0 & 11 & 0 & 0 & 0 & 0 \\
\hline Marribium desertii stems & 0 & 0 & 0 & 0 & 0 & 0 \\
\hline Mentha longifolia leaves & 0 & 0 & $15 \mathrm{~mm}$ & $13 \mathrm{~mm}$ & 0 & $18 \mathrm{~mm}$ \\
\hline Mentha longifolia stems & $10 \mathrm{~mm}$ & $11 \mathrm{~mm}$ & $10 \mathrm{~mm}$ & 0 & 0 & 0 \\
\hline Pentzia monodiana & $12 \mathrm{~mm}$ & $11 \mathrm{~mm}$ & 0 & 0 & 0 & 0 \\
\hline Aerva javanica & $11 \mathrm{~mm}$ & 0 & $14 \mathrm{~mm}$ & $16 \mathrm{~mm}$ & $16 \mathrm{~mm}$ & $15 \mathrm{~mm}$ \\
\hline Solenostema argel stems & $11 \mathrm{~mm}$ & 0 & 0 & 0 & $11 \mathrm{~mm}$ & 0 \\
\hline Deverra scoparia & $11 \mathrm{~mm}$ & $11 \mathrm{~mm}$ & 0 & 0 & 0 & 0 \\
\hline Pulicaria incisa & $11 \mathrm{~mm}$ & $\begin{array}{l}13 \mathrm{~mm} \text { with a } \\
\text { slow growth }\end{array}$ & 0 & 0 & 0 & 0 \\
\hline
\end{tabular}




\section{Discussion}

According to spots intensity and number, the most antioxidant extracts are those of Lavandula antinea (stems and leaves), Mentha longifolia (leaves), Pentzia monodiana and Deverra scoparia. This antioxidant activity may be explained by the presence of tannins and flavonoïds (Bruneton, 1993; Cavin, 1999a), which are free radicals trappers.

Cavin (1999b) demonstrated that aqueous extract of Lamiaceae had less antioxidant activity by TLC, with unclear spots, especially for aqueous extract of Thymus vulgaris because of their low active components levels that may be due to the method extraction used (extraction by maceration with water). Whereas, the methanolic extract of Thymus vulgaris showed the most capacity trapper of radical DPPH.

Moreover, among the aqueous extracts assayed, Maerua crassifolia presented the lowest antioxidant activity.These results were consistent with those of (Diallo, 2005) with the aqueous extract macerated leaves of the same plant (data not published).

Our results reported that the DPPH reduction by spectrophotometric assay showed that Lavandula antinea extracts (stems and leaves) had a higher antioxidant capacity in comparison with BHA control; this activity might be attributed to the phenolic compounds richness. Similar data were observed with the aqueous extract of Thymus vulgaris leaves (Kulšic et al., 2006). In this extract, polyphenols such as flavonoids, acid rosmarinic, caffeic acid and $\alpha$-tocopherol can explain the revealed activity (Guillén \& Manzanos, 1998; Thuille et al., 2003; Kulšic et al., 2006). The less significant activity compared to BHA was obtained with Balanites aegyptiaca. For the same plant, the antioxidant activity is variable from one organ to another (Wagner \& Bladt, 1996). In our investigation, Lamiaceae species did not present this variability which is only noted for Marribium desetii, its leaves had low activity and its roots do not show any activity. The isolated compounds (diterpens) from the arial part of this Algerian endemic species presented antiradical, antibacterial and antigenotoxic activities (Zaabat et al., 2010). Our phytochimic study revealed richness in some compounds and the lack even absence of other ones. Some species had shown the presence of saponosids and the cardiotonic glycosides. Flavonoids were the most common compounds in all studied species. Markham et al. (1982) showed that anthocyanins-3-glycosides where detected by orange, red and purple spots, while, flavonols by yellow and green spots. Flavones methylate, flavones, isoflavones, flavanones and chalcones appeared as blue spots. The flavanols and the aurones are characterized by the appearance of the green spots.

A comparative study between phytochimical and antioxidant activity by DPPH TLC showed that some bands represent the same $R_{f}$ for some species, this explained the reason that flavonoïds, saponins and cardiotonic glycosides had antioxidant activity. Flavonoïds are recognized to have antioxidant activity (Torel et al., 1986; Husain et al., 1987; Shahidi \& Wanasundara, 1992; Harborne \& Williams, 2000; D'abrosca et al., 2007). The present study indicated that the antimicrobial activity was significant at $10 \mathrm{mg}$ of extract. There was a sensitivity of gram positive bacterium Bacillussubtilis to the majority of studied extracts. This could be explained by the fact that gram-positive bacteria was more sensitive than gram-negative bacteria, suggesting that difference in sensitivity was caused by repulsion between polyphenols and lipopolysaccharide walls of gram negative bacteria Generally, the sensitivity of bacteria against polyphenols depends on bacterial species and polyphenols structure (Ikigai et al., 1998).

Our findings showed that aqueous extracts fromMentha longifolia manifested high antifungal activity in leaves as compared to stems, but no activity was observed towards yeast. Such results could be explained by a difference in concentration of chemicals between both vegetal parts. Al-Bayati (2009) reported antifungal activity with different concentrations of Mentha longifolia essential oil on the majority of seven bacteria studied with a strong antifungal activity against Candida albicans. The richness of polyphenols and flavonoïds of Lavandula antinea extract did not indicate any antifungal and antibacterial activity. All plants of Lamiaceae family, known for their phenolic compounds, were proven as active against variety of micro-organisms (Gortzi et al., 2007). Aerva javanica appears as an interesting plant, it showed an antifungal activity against Candida albican sand all tested yeasts with considerable inhibition zones. We noted that aqueous extracts have a low antimicrobial activity. The comparative work between alcoholic and aqueous extracts showed that C. alata, $L$. camara and M. scaber alcoholic extracts produced a more significant inhibition zones than the aqueous ones at a $500 \mathrm{mg} / \mathrm{ml}$ concentration (Ali-Emmanuel et al., 2002). It could be stated from this analysis that each extract acts differently on micro-organisms. A given compound can have a significant effect on one germ or less or no effect on another.

Marcelline Adiko et al. (2014) tested some plants were harvested in their natural habitats. Aqueous and methanol extracts of dried material were screened for antimicrobial activity, by dilution in solid culture medium, against 
six bacterial species responsible for ocular infections. Seven extracts were active against all bacteria methanol extracts of Hibiscus asper (Malvaceae), Hoslundia opposita (Lamiaceae), O. gratissimum, S. mombin, Vitellariaparadoxa (Sapotaceae) and Z. zanthoxyloides (bark); aqueous extracts of Piliostigma thonningii (Fabaceae) and S. mombin.

\section{Conclusion}

This work revealed the richness of medicinal flora from extreme southern Algeria which is traditionally used in the treatment of several diseases. Our phytochemical and biological activitie studies have been focused on the aerial parts, leaves and stems. The phytochemical analysis revealed the presence of saponins, cardiac glycoside sand flavonoids. Some tested extracts have the capacity to scavenge free radicals. Antibacterial, antifungal, and anti-oxidant activities were demonstrated for certain plants Lavandula antinea (stems and leaves), Mentha longifolia (leaves), Pentzia monodiana, Deverra scoparia and Aerva javanica.

\section{Acknowledgements}

The first author would like to thank Professor Hocine Allali from the University of Tlemcen. Dr. Zineb Boukhatem and Professor Hichem Mortad from the University of Oran. Thank them for reading and correcting the manuscript.

\section{References}

Al-Bayati, F. (2009). Isolation and identification of antimicrobial compound from Mentha longifolia L. leaves grown wild in Iraq. Annals of Clinical Microbiology and Antimicrobials, 8(20). http://dx.doi.org/10.1186/1476-0711-8-20

Ali-Emmanuel, N., Moudachirou, M., Akakpo, A. J., \& Quetin-Leclercq, J. (2002). Activités antibactériennes in vitro de Cassia alata, Lantana camara et Mitracarpusscaber sur Dermatophilus congolensis isolé au Bénin. Pays trop. Revue. Élev. Méd. Vét., 55(3), 183-187.

Bellakhdar, J., Claisse, R. J., \& Younos, C. (1991). Repertory of standard herbal drugs in the Moroccan pharmacopoea. J. Ethnopharmacol., 35, 123-143. http://dx.doi.org/10.1016/0378-8741(91)90064-K

Benamar, H., Rached, W., Derdour, A., \& Marouf, A. (2010). Screening of Algerian medicinal plants for acetylcholinesterase inhibitory activity. J. Biol.Sci., 10, 1-9. http://dx.doi.org/10.3923/jbs.2010.1.9

Blois, M. S. (1958). Antioxydant determination by the use of a stable free radical. Nature, 181, 1199-1200. http://dx.doi.org/10.1038/1811199a0

Bo Huang, J., Xiaoquan, H., Hong Zeng, B., Xincheng, Y., \& Youwei, W. (2011). Antioxidant activity of bovine and porcine meat treated with extracts from edible lotus (Nelumbonucifera) rhizome knot and leaf. Meat Science, 87, 46-53. http://dx.doi.org/10.1016/j.meatsci.2010.09.001

Bruneton, J. (1993). Pharmacognosie, Phytochimie et plantes médicinales (2nd ed., Technique et Documentation, p. 914). Paris.

Burns, R. E. (1971). Methods for estimation of tannin in grain sorghum. J. Agrom., 63, $511-512$. http://dx.doi.org/10.2134/agronj1971.00021962006300030050x

Cavin, A. (1999a). Investigation phytochimique de trois plantes indonésiennes aux propriétés antioxydantes et antiradicals Tinospora crispa (Menispermaceae); Merremiae marginata (Convolvulaceae) et Oropheaenneandra (Annonaceae) (Thesis). Univ. Lausanne, Suisse.

Cavin, A., Wahjo, D., \& Kurt, H. (1999b). Screening of Indonesian Plants for Antifungal and Free Radical Scavenging Activities. Pharmaceutical Biology $\quad$ J., $\quad 37(4), \quad$ 260-268. http://dx.doi.org/10.1076/phbi.37.4.260.5800

D’abrosca, B., Pacifisco, S., Cefarelli, G., Mastellone, C., \& Fiorentino, A. (2007). Limoncella' apple, an Italian cultivar: Phenolic and flavonoid contents and antioxidant activity. Food Chem., 104, 1333-1337. http://dx.doi.org/10.1016/j.foodchem.2007.01.073

De Oliveira, T. L., de Araújo Soares, R., Ramos, E. M., das Graças Cardos, M., Alves, E., \& Piccoli, R. H. (2011). Antimicrobial activity of Satureja montana L. essential oil against Clostridium perfringens type A inoculated in mortadella-type sausages formulated with different levels of sodium nitrite. Int. J. Food Microbiol., 144, 546-555. http://dx.doi.org/ 10.1016/j.ijfoodmicro.2010.11.022

Diallo, A. M. (2005). Étude des plantes médicinales de Niafunke (région Tanbouktou). phytochimie et pharmacologie de MareuacrassifoliaForsk (Capparidacée) (Unpublished Thesis). Faculté de Médecine de 
Pharmacie et d'Odonto-Stomatologie., Univ. Bamako., Mali.

Djeridane, A., Yousfi, M., Nadjemi, B., Boutassouna, D., Stocker, P., \& Vidal, N. (2006). Antioxydant activity of some Algerian medicinal plants extract containing phenolic compounds. J. Food Chem., 97, 654-660. http://dx.doi.org/10.1016/j.foodchem.2005.04.028

Dominguez, M., Nieto, A., Marin, J. C., Keck, A. S., Jeffery, E., \& Cespedes, C. L. (2005). Antioxidant activities of extract from Barkleyanthussalicifolius (Asteraceae) and Penstemongentianoides (Scrophulariaceae). J. Agri. Food Chem., 53, 5889-5895. http://dx.doi.org/10.1021/jf0504972

Eddouks, M., Maghrani, M., Lemhadri, A., Ouahidi, M. L., \& Jouad, H. (2002). Ethnopharmacological survey of medicinal plants used for the treatment of diabetes mellitus, hypertension and cardiac diseases in the southeast region of Morocco (Tafilalet). J. Ethnopharmacol, $82, \quad 97-103$. http://dx.doi.org/10.1016/S0378-8741 (02) 00164-2

Gast, M. (1968). Alimentation des populations de l'Ahaggar: étude ethnographique. Mém. Cent. Rech. Anthrop. Préhist. Ethnog. (8th ed., p. 457). Arts et Métiers graphiques. Paris.

Gortzi, O., Lalas, S., Chinou, I., \& Tsaknis, J. (2007). Evaluation of the Antimicrobial andAntioxidant Activities of Origanum dictamnus Extracts before and after Encapsulation in Liposomes. Molecules, 12, 932-945. http://dx.doi.org/10.3390/12050932

Guillén, M. D., \& Manzanos, M. J. (1998). Study of the composition of the different parts of a Spanish Thymus vulgaris L. plant. Food Chem., 63(3), 373-383. http://dx.doi.org/10.1016/S0308-8146(98)00013-2

Harborne, J. B., \&.Williams, C. A. (2000). Advances in flavonoid research since 1992. Phytochem., 55(6), 481-504. http://dx.doi.org/10.1016/S0031-9422(00)00235-1

Husain, S. R., Cillard, J., \& Cillard, P. (1987). Hydroxyl radical scavenging activity of flavonoids. Phytochem., 26, 2489-2492. http://dx.doi.org/10.1016/S0031-9422(00)83860-1

Ikigai, H., Nakae, T., Hara, Y., \& Shimamura, T. (1998). Chemotherapy, 46, 179-183.

Kaisoona, O., Siriamornpun, S., Weerapreeyakul, N., \& Meesoc, N. (2011). Phenolic compounds and antioxidant activities of edible flowers from Thailand. J. Functional Foods, 3, 88-99. http://dx.doi:10.1016/j.jff.2011.03.002

Karou, D., Dicko, M. H., Sanon, S., Simpore, J., \& Traore, A. S. (2003). Antimalarial activity of Sida acuta Burm. F. (Malvaceae) and Pterocarpus Erinaceus Poir. (Fabaceae). J. Ethnopharmacol, 89, 291-294. http://dx.doi.org/10.1016/j.jep.2003.09.010

Kim, D. O., Jeong, S. W., \& Lee, C. Y. (2003). Antioxidant capacity of phenolic phytochemicals from various cultivars of plums. Food Chem., 81, 321-326. http://dx.doi.org/10.1016/S0308-8146(02)00423-5

Kulšic, T., Dragovic-Uzelac, V., \& Miloš, M. (2006). Antioxidant Activity of Aqueous Tea Infusions Prepared from Oregano, Thyme and Wild Thyme. Food Technol. Biotechnol., 44(4), 485-492.

Marcelline, A., Sylvie, B., Timothée, A. O., Sylvie, L., Laurent, A., Brou, J. K., \& Pierre, C. (2014). Phytothérapie traditionnelle des conjonctivites en milieu urbain ivoirien :enquête sur les deux marchés aux plantes médicinales d'Abidjan. Acta Bot. Gallica., $161(1), \quad$ 33-45. http://dx.doi.org/10.1080/12538078.2013.864998

Markham, K. R. (1982). Techniques of Flavonoid Identification Biological techniques series (p. 113). Academic Press, London.

Rached, W., Benamar, H., Bennaceur, M., \& Marouf, A. (2010). Screening of the antioxidant potential of some Algerian indigenous plants. J. Biol.Sci., 10(4), 316-324. http://dx.doi.org/10.3923/jbs.2010.316.324

Sahki, A., \& Sahki, R. (2004). Le Hoggar promenade botanique (Ed. Ésope. Lyon., p. 311).

Sahki, R. (1998). Les plantes naturelles utilisées pour guérir les affections dues aux animaux venimeux scorpions et serpents dans l'Ahaggar. Rev. FOREM. Santé +. Alger., 61, 11-16.

Sahki, R. (2012). Contribution à l'étude de phytoécologique et inventaire des plantesmédicinales du Sahara central (Feuilles d'Assekrem au 1/200000) (Unpublished Thesis). F.S.B. Univ. U.S.T.H.B., Algeria.

Shahidi, F., Janitha, P. K., \& Wanasundara, P. D. (1992). Phenolic antioxidants. Critical Review in Food Science and Nutrition, 32, 67-103. http://dx.doi.org/10.1080/10408399209527581

Singleton, V. L., \& Rossi, J. A. (1965). Colorimetry of total phenolics with phosphomolybdic-phosphotungstic 
acid reagents. Am. J. Enol. Vitic., 16, 144-158.

Thuille, N., Fille, M., \& Nagl, M. (2003). Bactericidal activity of herbal extracts. Int. J. Hug.Environ.Health, 206, 217-221. http://dx.doi.org/10.1078/1438-4639-00217

Torel, J., Cillard, J., \& Cillard, P. (1986). Antioxidants activities of flavonoids and reactivity with peroxy radical. Phytochem., 25, 383-385. http://dx.doi.org/10.1016/S0031-9422(00)85485-0

Wagner, H., \& Bladt, S. (1996). Plant drug analysis.A thin layer chromatography atlas (2nd ed., p. 384). Springer-Verlag Berlin Heidelberg, New York. http://dx.doi.org/10.1007/978-3-642-00574-9

Yemoa, A. L., Gbenou, J. D., Johnson, R. C., Djego, J. G., Zinsou, C., Moudachirou, M., ... Portaels, F. (2008). Identification et étude phytochimique de plantes utilisées dans le traitement traditionnel de l'ulcère de Buruli au Bénin. Ethnopharmacologia, 42.

Zaabat, N., Darbour, N., Bayet, C., Michalet, S., Doléans-Jordhéim, A., Chekir-Ghedira, L., Akkal, S., \& Dijoux-Franca, M. G. (2010). Etude préliminaire de Marribium desertii de Noé, une lamiaceae endémique Algérienne. Phytothérapie, 8, 353-358. http://dx.doi.org/10.1007/s10298-010-0589-y

Ziyyat, H., Legssyer, A., Mekhfi, H., Dassoili, A., Serhrouchni, M., \& Benjelloun, W. (1997). Phytotherapy of hypertension and diabetes in oriental Morocco. J. Ethnopharmacol, 58, $45-54$. http://dx.doi.org/10.1016/S0378-8741(97)00077-9

\section{Copyrights}

Copyright for this article is retained by the author(s), with first publication rights granted to the journal.

This is an open-access article distributed under the terms and conditions of the Creative Commons Attribution license (http://creativecommons.org/licenses/by/3.0/). 